\title{
Career Decision Making Process in Adolescence: Theoretical Perspective
}

\author{
Sumbul Abid \\ University of Delhi, India
}

\begin{abstract}
Choosing a career path might help the students set professional goals and develop a strategy for getting where they want to be. Part of choosing an appropriate career path involves making an honest selfevaluation of the talents, abilities and interests. The theoretical perspective on Career development has been explored in this article in relation to the process of career decision making of adolescents who are in the transition phase from college to school and the importance of the same.
\end{abstract}

\section{INTRODUCTION}

Students all over the world are usually faced with the task of career decision making. The choice of careers, subjects, and courses of study in schools and of subsequent paths to follow is always difficult problems facing prospective undergraduates. Often, choosing the right subject combination leading to the right profession can make the difference between enjoying and detesting the career in future. Dedicating oneself to career choices that are unattainable leads to frustration. Each individual undertaking the process is influenced by many factors, including the context in which they live, their personal aptitudes, and educational attainment (Bandura, et al. 2001).General agreement exists on the position that to be able to successfully cope with the myriad challenges that await them in the world of work (e.g., job changes, part-time and temporary contract work), young people need to learn and be able to effectively use self-directing agentic skills (Betz \& Hackett, 1987).

Collin (1998) explains that the term career arises from the interaction of individuals with organisations and society. This interaction, as Savickas (2009) proposes, is no longer merely just a sequence of jobs but is now a story that working people build about themselves. The term "Career" can therefore be defined as the sequence of interaction of individuals with society, education and organisations throughout their lifespan, if we take a developmental approach.

Various theories of Career Development have been formulated by number of researchers stating the process of career development and what it takes to decide and settle on a career path by the students. The process of selection of a particular career path is not only confusing and frustrating but stressful too. The very process of the difficult task of Career Decision making may lead to stress in the students who are in the phase of selecting a career path for them. Stress can be thought of a mismatch between person and his or her environment (person-environment misfit). It is surprising that no definition of the term "Stress" has been universally accepted even among the majority of stress researchers ( Elliot \& Eisdorfer, 1982). Lazarus (1984) defined stress as "a relationship between the person and the environment that is appraised as taxing or exceeding his or her resources and endangering his or her wellbeing.

\section{MAJOR THEORIES OF CAREER DEVELOPMENT}

\section{John Holland's Theory of Vocational Personalities in Work Environment}

Holland formulated a theory according to which vocational interest is an expression of one's personality, and that vocational interests could be conceptualised into six personality types, which are Realistic (R), Investigative (I), Artistic (A), Social (S), Enterprising (E), and Conventional (C). If a person's degree of resemblance to the six vocational personality and interest types could be assessed, then it is possible to summarise one's career interest. Parallel to the classification of vocational interest types, Holland $(1985,1997)$ postulated that vocational environments could be arranged into similar typologies. In the career choice and development process, people search for environments that would allow them to exercise their skills and abilities, and to express their attitudes and values. In any given vocational environment, there is a tendency to shape its composition so that its characteristics are like the dominant persons in there, and those who are dissimilar to the dominant types are likely to feel unfulfilled and dissatisfied. The concept of "congruence" is used by Holland to denote the status of person-environment interaction. A high degree of match between a person's personality and interest types and the dominant work environmental is likely to result in vocational satisfaction and stability, and a low degree of match is likely to result in vocational dissatisfaction and instability. 


\section{Self Concept Theory by Super}

The Self concept theory of Career development by Super has received much attention in the field of Career development especially in USA. Super $(1969,1980,1990)$ suggested that career choice and development is essentially a process of developing and implementing a person's self-concept. According to Super (1990), self-concept is a product of complex interactions among a number of factors, including physical and mental growth, personal experiences, and environmental characteristics and stimulation. Super (1990) proposed a life stage developmental framework with the following stages: growth, exploration, establishment, maintenance (or management), and disengagement. In each stage one has to successfully manage the vocational developmental tasks that are socially expected of persons in the given chronological age range. For example, in the stage of exploration (ages around 15 to 24), an adolescent has to cope with the vocational developmental tasks of crystallisation (a cognitive process involving an understanding of one's interests, skills, and values, and to pursue career goals consistent with that understanding).

\section{Social Cognitive Career Theory by Albert Bandura}

Social Cognitive Career Theory (SCCT) (Lent, Brown, \& Hackett, 2002; Lent, 2005) is anchored in Bandura's self-efficacy theory (1977, 1997), which postulated a mutually influencing relationship between people and the environment. Lent (2005) defined self-efficacy as "a dynamic set of beliefs that are linked to particular performance domains and activities" (p. 104). The SCCT choice model views the development of career goals and choices as functions of the interaction among self-efficacy, outcome expectations and interest over time. There are other theories as well which talks about various approaches to career development and its process such as Gottfredson's Theory of Circumscription and Compromise and trait and Factor theory by Frank Parsons but these three theories are the popular ones which enhance the understanding of the whole process of Career decision Making process.

\section{CONCLUSION}

There is a growing need to understand the problems students face while selecting a particular career because choosing a career is not only important in terms of employability or just being there but a person is required to invest his or her whole life in that career which needs wise decision. The theories of career development can prove to be really helpful in order to understand the underlying process involved in Career decision Making and also, the factors which might be responsible for creating confusion or mismatch in the person-environment fit with respect to Career. Awareness of such theories would not only help individual in knowing the underlying developmental process but these theories can be used as a base to recognize the gaps in career decision making which is the crucial part of a student's life, especially those in transition phase from school to college. Career selection is one of many important choices students will make in determining future plans. This decision will impact them throughout their lives. The essence of who the student is will revolve around what the student wants to do with their life-long work. Therefore it becomes necessary for Career and Guidance professionals also to take into consideration the and how of these theories as well.

\section{REFERENCES}

[1] Bandura, A., Barbaranelli, C., Caprara, G.V. and Pastorelli, C. (2001) Self-efficacy Beliefs as Shapers of Children's Aspirations and Career Trajectories. Child Development. 72: 187-206.

[2] Betz, N. E., \& Hackett, G. (1987). Concept of agency in educational and career development. Journal of Counseling Psychology, 34, 299-308.

[3] Holland, J. H. (1997). Making vocational choices: A theory of vocational personalities and work environments (3rd ed.). Englewood Cliffs, NJ: Prentice-Hall.

[4] Lent, R. W., Brown, S. D., \& Hackett, G. (2002). Social cognitive career theory. In D. Brown \& Associate (Eds.), Career choice and development (4th ed., pp. 255-311). San Francisco, CA: JosseyBass.

[5] Super, D. W. (1980). A life-span, life-space approach to career development. Journal of Vocational Behavior, 16, 282-298. 